\title{
БАЛАНСОТЕРАПИЯ ДЛЯ ВОССТАНОВЛЕНИЯ ФУНКЦИИ РАВНОВЕСИЯ У ПАЦИЕНТОВ, ПЕРЕНЕСШИХ КОМПРЕССИОННЫЕ ПЕРЕЛОМЫ ПОЗВОНКОВ НА ФОНЕ ОСТЕОПОРОЗА
}

\author{
Макарова Е.В., Марченкова Л.А., Еремушкин М.А., Стяжкина Е.М., Разваляева Д.В. \\ ФГБУ «НМИЦ реабилитации и курортологии» Минздрава России, Москва
}

АКТУАльнОСТь: медицинская реабилитация, нацеленная на тренировку равновесия, является важной мерой профилактики падений и повторных переломов у лиц, уже перенесших остеопоротические (ОП) переломы.

ЦЕЛЬ: оценить влияние комплекса физической реабилитации на функцию равновесия у пациентов с ОП компрессионными переломами позвонков (ПП).

МАТЕРИАЛЫ И МЕТОДЫ: проведено проспективное контролируемое исследование мужчин и женщин 40-80 лет с ОП ПП, поступивших на медицинскую реабилитацию. Пациенты были разделены на две группы методом простой рандомизации в соотношении 2:1. Группа вмешательства (№1) получала интенсивный курс реабилитации, включавший: 1) тренировку мышц спины (Back Therapy Center, DrWolff, Германия) №10; 2) сенсомоторную тренировку (КОБС, Physiomed, Германия) №10; 3) кинезогидротерапию в бассейне, №15; 4) лечебную физкультуру по методике Гориневской-Древинг, №10. Группа контроля (№2) получала только лечебную физкультуру по методике Гориневской-Древинг. До начала реабилитации всем пациентам было проведено: 1) исследование функции равновесия помощью стабилометрии (на аппарате Стабилан 1.0); 2) координационные тесты (стойка на одной ноге, Fukuda-Unterberger). Повторное обследование проводилось после реабилитации и через месяц после окончания курса.

РЕзУЛЬтАТЫ: в исследование было включено 90 человек ( $\mathrm{n}=60$ в группе 1, n=30 в группе 2), в возрас-

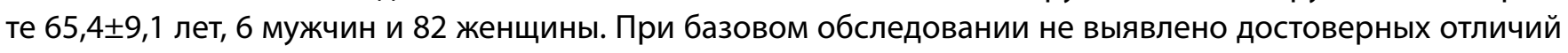
показателей стабилометрии и координационных тестов (р>0,05). В группе 1 после курса реабилитации достоверно улучшились показатели: коэффициента функции равновесия (КФР) с открытыми и закрытыми глазами $(84,1 \pm 8,6 \% \Delta+7,1, \mathrm{p}=0,01$ и 73,8土9,6\% $\Delta+6,7, \mathrm{p}=0,01$ соответственно); смещения по фронтали (СФ) $(1,9[0,7 ; 2,4], \Delta-2,8, \mathrm{p}=0,01)$, площадь статокинезиограммы (СКГ) $\left(131,9\right.$ мм² $\left.^{2} \Delta-44,9, \mathrm{p}=0,04\right) ;$ скорость перемещения центра давления (ЦД) $(12,2 \pm 10,1 \mathrm{~mm} / \mathrm{c}, \Delta+3,3, \mathrm{p}=0,001)$; в тесте Фукуды сократилось смещение в градусах $(32,8 \pm 14,5, \Delta-8,8, p=0,03)$, а в тесте «Стойка на одной ноге» улучшилось время для правой и левой ноги с открытыми глазами $(17,8 \pm 31,8$ c, $\Delta-8,1, \mathrm{p}=0,001,17,1 \pm 30,1$ соответственно). В группе 2 наблюдалось: достоверное улучшение в отношении СФ $(2,1[1,9 ; 5,2], \Delta-2,0, p=0,001)$; скорости перемещения ЦД $(10,1 \pm 3,9$ мм/с $\Delta+1,0, \mathrm{p}=0,05)$. Через месяц после курса реабилитации в группе 1 сохранялась положительная динамика по параметрам: КФР с открытыми и закрытыми глазами, СФ, скорость перемещения ЦД, площадь СКГ, смещение в метрах и градусах в тесте Фукуды, время стояния на правой и левой ногах с открытыми и закрытыми глазами. Данные показатели в группе 1 достоверно отличалась от результатов в группе $2(p<0,01)$.

ВЫВОдЫ: комплекс физической реабилитации, нацеленный на тренировку мышц спины и координации, улучшал функцию равновесия у пациентов, перенесших ОП ПП. Корректировалось патологическое смещение ЦД вперед по фронтали и повышалась устойчивость. Стабилометрия и координационные тесты служат достоверными методами для оценки функции равновесия у этой группы больных. 